\title{
Popular Author of Popular Art
}

\author{
Marcin Jaworski \\ Nicolaus Copernicus University in Toruń, Poland \\ E-mail address: maul@poczta.onet.pl
}

ARTICLE INFO

\section{Keywords:}

Wróblewski

Comic book

Popular culture

Popular art

Article history:

Received 20 February 2016

Received in revised form 27 April 2016

Accepted 1 May 2016

ISSN: 2354-0036

DOI: 10.1515/ctra-2016-0009

\section{A B STRACT}

The article provides a report on research conducted on the creative activity of Jerzy Wróblewski, a Polish author of comics published in the book "Urodzony, żeby rysować”. Twórczość komiksowa Jerzego Wróblewskiego, "Born to Draw." Jerzy Wróblewski's Comic Art (Jaworski, 2015). It is the first study of this kind in Poland. From this point of view, it contains not only a body of knowledge in the form of a monograph of the comic writer's artistic creativity, but it also includes a developed research model. The structure of this model, combining traditional monographic narrative with broad historical, political and social context, can be used in the analyses of artistic accomplishments of other authors of Polish comics. The presented study addresses the need for scientific explorations in this field, but also for raising the value of those parts of Polish modern culture which were marginalised as 'worse' for many years, first for political reasons, then for cultural ones. It appears that the time has come to examine critically the artistic creativity of important figures of Polish popular culture (in this case of comics) objectively and without ideological prejudice, and recognise them as full authors of Polish culture. Jerzy Wróblewski is among them and that is why the book is about him.

\section{AN UNDEVELOPED RESEARCH FIELD}

The works of Polish comic writers have never been seriously examined in Poland. This is hardly surprising, as throughout the whole post-war period, comics were treated as an ideologically suspicious manifestation of Western popular culture, and a long-term media campaign established a negative image of this medium in society as trivial and having a detrimental effect on the development of children and young people. That is why the first book about comics in Poland was not written until 1985, which is almost a hundred years after the first comic work was published. It was written by Krzysztof Teodor Toeplitz Sztuka komiksu. Próba definicji nowego gatunku artystycznego, The Art of Comics. An Attempt to Define a New Art Type (Toeplitz, 1985). Nevertheless, serious re- 
search started much later in Poland. In the 1990s Jerzy Szyłak initiated it by exploring the issues of the history and the visual language of comics (Szyłak, 1998, 2000, 2000). In this context, the analyses of the history of Polish comics conducted by Adam Rusek (Rusek, 2001, 2010, 2011) are equally important. Up until now, no monographic study comprehensively covering the artistic creativity of a Polish comic writer has been written. The book „Urodzony, żeby rysować”. Twórczość komiksowa Jerzego Wróblewskiego, "Born to Draw." Jerzy Wróblewski's Comic Art is the first attempt of this kind in Poland. The study Grzegorz Rosiński. Monografia, Grzegorz Rosiński. A Monograph is not, contrary to its title, such an attempt; it is rather an album presenting the comics and illustration works of the exceptional cartoonist along with interviews (Gaumer P., Rosiński P., 2015). As mentioned, the history of research on comics in Poland is long overdue which is the result of unfavourable historical and political conditions and also the lack of a tradition of such analyses. What is lacking in particular is an in-depth monographic study on the artistic creativity of selected authors of Polish comics. This should be a study that would build a broad (not just fragmented) knowledge of Polish comics anchored in the broader context, not only aesthetic, but also social and political. Why is such knowledge worth building? Not only for collecting information of a specialist character, in this case about the history of Polish comics, but also in order to celebrate the work of one of the classic writers of this medium in Poland, Jerzy Wróblewski. It is worth understanding how vast and undeveloped an area of knowledge this is. The monograph „Urodzony, żeby rysować". Twórczość komiksowa Jerzego Wróblewskiego, "Born to Draw.” Jerzy Wróblewski's Comic Art is, as has been mentioned, was the first study of this kind on the artistic creativity of the Polish classic author of comics. Other writers like Grzegorz Rosiński, Janusz Christa, Henryk Jerzy Chmielewski, Tadeusz Baranowski, Szymon Kobyliński, Marek Szyszko, Szarlota Pawel are "waiting their turn"... And the problem does not concern only comic artists, but also illustrators like, for example, Jan Marcin Szancer or Daniel Mróz and satirical cartoonists such as Andrzej Mleczko, Antoni Chodorowski or Julian Bohdanowicz. Many such artists of popular culture are waiting for critical description. Why has research on their work not yet been undertaken? Probably because of the conviction, firmly grounded in the Polish humanities (shared by many people), concerning popular culture, which is seen as a separate (and worse) part of culture and thus drawing a line between popular culture and high culture, though it is obvious that such divisions mean little in the practice of creating and consuming culture and art in the modern world. A different belief is slowly becoming widespread, on the basis of which, culture in the modern world is not characterised by a hierarchical structure but which allows it to be created and received in many ways, from the most refined forms to very egalitarian ones, and the re- 
lationships between the two are quite dynamic. In such a heterogeneous model of culture, it is natural to concentrate attention on artists, who can be called creators of popular culture. The aforementioned comic artists deserve to be called classics of this kind and to be considered full creators of Polish culture. In the case of Rosiński, Christa and Baranowski, such official recognition by the state has already happened, since the cartoonists have been recognised as distinguished creators of Polish culture. Unfortunately, Jerzy Wróblewski was not, as he died before these processes started. It is therefore paradoxical that one of the classics of Polish comics was not recognised as a creator of Polish culture. Moreover, fans and experts are familiar with his work, but they do not know who the author was, how his creativity developed over the years, or what inspired him. In undertaking my research on his work I intended to highlight the necessity for including him in the group of creators of Polish culture (along with his distinguished friends). I also aimed at presenting the cartoonist, who died in 1991, to his readers.

\section{RESEARCH EXECUTION}

Achieving the goal of presenting the comic works of Jerzy Wróblewski in detail that I had set myself turned out to be somewhat difficult. The disproportion between his work and the relatively small amount of source materials, by which I mean his statements, critical studies on his work, articles or reviews of his work, was striking. The artist did not leave any commentaries on his own work. Neither was he interviewed. Why? The cartoonist, prematurely deceased at the age of 50 , worked during the communist period and at that time nobody sought such information. For that reason, my research work was almost that of a 'detective', that is, it required the painstaking collection of materials and their interpretation. The information was obtained by talking to his relatives and co-workers for hours, from searches of the press, and from the analysis of archival materials such as correspondence with publishers or supporting materials that the cartoonist needed during his work. Developing an adequate model of analysis which would result in creating a monograph about the Polish author of comics constituted another challenge closely connected with the unprecedented character of the undertaken research. How was it developed? In my research on Jerzy Wróblewski's comic work I chose to use two overlapping paths of scientific exploration. The first one looked at his work as an aesthetic and artistic phenomenon, while the other allowed his artistic activity to be placed in a wider historical, social and political context. Therefore, it can be stated that the study consisted of the traditional structure of a monograph about an artist, within which the particular stages of his career as an author of comics, his work, as it was created over the years, and its formal analysis were presented in chronological order. Also, the influence of powerful non-artistic factors, for example geopolitical changes, which determined the socio- 
political situation of Poland in the post-war period, including the model of culture present at that time, were taken into account. The interpenetration of these contexts in the narration was necessary in order to present the complexity of the cartoonist's situation in the post-war period in Poland reliably. It required reference to knowledge of such areas as history and sociology. My work consisted of several stages.

In the first unit (Genealogia twórczości Jerzego Wróblewskiego, Genealogy of Jerzy Wróblewski's Artistic Creativity) I looked for the sources of his work. I identified two such sources. Firstly, I saw them as arising within the universal basis of any form of creativity, that is the 'long-time' tradition of telling stories. Secondly, I found them in the history of comics, that is, in the tradition of telling stories by means of sequential pictures and the ludic tradition of this medium. On the one hand, the point was to emphasise the most characteristic features of Wróblewski's work such as the passion for telling stories, ludic narratives and the element of adventure; on the other hand, I wanted to relate them to the aforementioned elements appearing in the old tradition of culture and in the culture of comics.

In the second unit (W poszukiwaniu zasobów twórczości Jerzego Wróblewskiego. Okres przedwojenny i czas II wojny światowej, Looking for the Resources of Jerzy Wróblewski's Works. The Pre-war Period and World War II) I aimed at presenting the resources Jerzy Wróblewski could use at the time of his debut in 1959 in the form of the Bydgoszcz afternoon newspaper "Dziennik Wieczorny". In order to achieve this, it was necessary to explain how developed the comics tradition was in Poland, not only in the post-war period, but also earlier, in the pre-war period. The point was to answer the question concerning that of the forefathers and masters whose works were examples that the post-war authors followed; how advanced were the publishing system and the press before the war; what forms of picture narration were particularly popular in Poland at that time and why; what topics dominated, etc. Examining pre-war comics in this respect made it possible to explain, for example, why such archaic forms of narration as picture stories were so popular in Poland as early as in the mid-1970s. Most of all, these considerations were important for indicating the problem of discontinuity of the comics tradition in Poland, disturbed in its natural development by traumatic events such as the German occupation or the following Stalinist period. This discontinuity meant that young cartoonists, debuting after the war, had to build the national comics culture almost from scratch. In addition, I identified two factors which allowed the tradition to survive the worst times. The memory of this tradition and the need to be a participant in its course were nurtured by both authors and young readers of picture stories and comic books. Jerzy Wróblewski and the cartoonists of his generation like Grzegorz Rosiński (not to mention older ones like Henryk Jerzy Chmielewski and Janusz Christa) identified with these values and when 
a more favourable political climate for writing comics appeared, they were able to relate to those values. In this unit, it was necessary to examine the author's writing skills and I presented the resource materials he used in his work. I analysed his home 'archive', which included the picture stories he collected, other authors' comics, various supporting materials, media and tools needed to work. In demonstrating these resources I gained access to the author's skills and it also allowed me to think about the inspirations and formal influences under which he found himself.

In the third unit (Komiks polski w latach 1945-1956, Polish Comics in the Years 1945-1956) I presented the socio-political context of the post-war years and its influence on the development of the comics culture in the communist era. I started with an analysis of the time of the 'mild revolution', through the Stalinist period to the first symptoms of the 'political thaw' in 1956. It was necessary to present basic historical facts about the conditions of post-war Poland, searches of the press in this period and to make a connection between this information and the situation of comics at that time. The point was also to portray Jerzy Wróblewski (and his friends - comic artists) as representatives of the generation that entered adulthood after the war and that after Hanna Świda-Zięba I call the generation of 'cultural opposition'. A characteristic feature of young people at that time was their fascination with Western popular culture including comics. Including this thread was really important in order to understand Jerzy Wróblewski and his friends' astonishing determination to be interested in comics and even to start working on them in view of the authorities' negative attitude towards Western popular culture. I proposed that the fascination resulted not from opposition in terms of political involvement, but from aesthetic involvement and opposition. Wróblewski, fascinated with Western popular music, comics, westerns and fashion, was a great representative of the 'cultural opposition'. In the following parts of the book I focused my attention on an analysis of Wróblewski's comic art, that is, his comic strips and comics. I drew attention to the moments of breakthrough in his career for his artistic biography presented in chronological order.

In the fourth unit of the book (Współpraca Jerzego Wróblewskiego z „Dziennikiem Wieczornym" w latach 1959-1978, Jerzy Wróblewski's Cooperation with "Dziennik Wieczorny" in the Years 1959-1978), I presented the fruit of his cooperation with the Bydgoszcz afternoon newspaper "Dziennik Wieczorny". Wróblewski, as a comic book and comic book script writer, created about 70 stories with over four thousand episodes. Firstly, given such rich research material, a well thought-out choice had to be made in order to select the most representative titles. I chose not to follow the standard criteria of selecting works by the order in which they were published in magazines. Bearing in mind the ludic sources of Wróblewski's works (described in the first unit), my decision was to ana- 
lyse the comic strips and comics with respect to those that were most characteristic for Wróblewski's artistic creativity ludic element, which was adventure. In examining these issues, I also characterised Polish tabloids after the political breakthrough in 1956. Analysing "Dziennik Wleczorny" I explained the special status of the newspaper (entertaining, not ideological), the shape of editorial sections (journalists with liberal views, also on popular culture) and most of all, how Wróblewski's cooperation with the Bydgoszcz newspaper developed in terms of technical advances and content. Moreover, I emphasised the influence of the afternoon press on renewing the comics tradition in Poland after the Stalinist period. Wróblewski, who debuted in "Dziennik Wieczorny" in 1959, was a good example. A seventeen-year-old student of the secondary school of fine arts in Bydgoszcz, he learnt the profession of a cartoonist in long, everyday work with the newspaper editors. There he gained the competencies and skills of a professional: punctuality in completing tasks, conscientiousness and industriousness, but also comprehensiveness in all topics he was told to cover. I attempted to analyse his work in the context of the gradual formation of his drawing style (grotesque and realistic), the appearance of his favourite threads of adventure (western) and the more and more intentional process of becoming the script writer for his comics. Non-artistc issues could not be avoided either. I focused on the increasingly clear and deliberate post-1956 ambition of the authorities' to use popular culture (including comics) in an instrumental way for educational and propaganda purposes. It was then that the principle that comics may exist so long as they play non-ludic roles was defined. That principle was applied until the end of the communist period and it set a real and closed framework for the work of Wróblewski and other authors of comics.

In chapter 5 of the book (Współpraca Jerzego Wróblewskiego z wydawnictwem „Sport i Turystyka”, Jerzy Wróblewski's Cooperation with the "Sport i Turystyka” Publishing Company) I presented Wróblewski's cartoons from the time of his cooperation with the "Sport i Turystyka" national publishing company. Most attention was devoted to the famous comic series which the cartoonist made in cooperation with other authors ('Underground Front', 'Captain Żbik'). I obviously did not forget about Wróblewski's other achievements from that time. In accordance with the adopted principle, I first outlined the historical, political and social background of Władysław Gomułka's (the First Secretary of the Polish Communist Party in the years 1956-1970) period of decline. In this context I emphasized that the ideological pressure exerted on culture by Mieczysław Moczar's nationalist communist camp was reflected in the comics drawn by Wróblewski and his friends. Another factor that started to determine the functions of comics in Poland (alongside ideological ones) were financial benefits. Referring to the correspondence between Wróblewski and the 'Sport i Turystyka' publishing company was interesting 
in terms of understanding the mechanisms and practice of cooperation between cartoonists and national publishing companies at that time. It made it possible to understand the individual situation of cartoonists in the face of the administrative power of publishing companies and of the pressure exerted by censorship. This asymmetrical system, in which authors were mere tools, reflected their low status in the eyes of, not only party publishers, but also of society as a whole. Details concerning the life situation of the artist, his material and family situation and career plans were presented in the narrative. In the sixth unit (Współpraca Jerzego Wróblewskiego z „Krajową Agencją Wydawniczą”, Jerzy Wróblewski's Cooperation with the "Krajowa Agencja Wydawnicza” Publishing Company) I examined the comics that resulted from Jerzy Wróblewski's work for "Krajowa Agencja Wydawnicza". I presented the most significant comic work created for 'Relax. Picture Stories Magazine' and other comics published in the form of separate albums. I also provided an introduction to the historical background of the Gierek (the First Secretary of the Polish Communist Party in the years 1970-1980) era, in this way presenting comics as an element of cultural policy (the 'propaganda of success') and of the opening up of the new authorities to the West. Another change in the national policy towards popular culture and comics was illustrated with appropriate quotations taken from the press at that time. The manifestation of that policy was 'Relax' magazine inspired by Western comic magazines. The unit also includes information concerning the mechanism of Wróblewski's cooperation with "KAW" and the office of "Relax" (based on the cartoonist's correspondence).

In the seventh unit of the book (Bez przymusu - od „Binio Billa” do „My nigdy nie śpimy”, Without Obligation - from "Binio Bill” to "We Never Sleep") I presented Wróblewski's last works. Most attention was devoted to discussing the western series "Binio Bill". The series was written in the 1980s for the "Świat Młodych" magazine and it was the cartoonist's, who was also its script writer, greatest achievement. Materials from Wróblewski's 'archive' were used to present unique sketches of individual panels, parts of comic scripts, sketches of characters and many more interesting elements. The works were created in a very interesting historical period at the end of the communist era and after the political breakthrough in 1989. The new political and economic situation meant the hope of positive change, and in the case of cartoonists, of the freedom for creative work without political pressure and censorship, as well as an improvement in their financial situation. Unfortunately, the hopes turned out to be in vain, because the early stages of Polish capitalism were marked by the fall of the old national publishing companies and the dishonesty of new publishers. For this reason, I focused on the work that for various rea- 
sons was not completed or the creation of which was interrupted by the cartoonist's death, like the western 'We Never Sleep'.

Since the aim of the book was to collect extensive knowledge of Jerzy Wróblewski's work, it was also necessary to include four lists that consisted of: a catalogue of Wróblewski's works, a list of exhibitions of his works, bibliographic data and the sources of illustrations. An index of names and an index of titles were presented separately.

I would like to emphasize that the value of the conducted study, which resulted in the monograph "Urodzony, żeby rysować". Twórczość komiksowa Jerzego Wróblewskiego, "Born to Draw." Jerzy Wróblewski's Comic Art, does not lie in the fact that it describes the achievements of the best Polish writer of comics in the post-war period, but in the fact that it presents the artistic achievements of the author, whose artistic creativity had (and still has) evident social resonance. It was also crucial to portray Wróblewski in the context of the time of his life and work. He (and his cartoonist friends) was an interesting 'case' of a creator of popular culture in the communist era, with all of its complex conditions like instrumentalisation, and ideological pressure, low social and artistic status on the one hand, but also the possibility of publishing comics in the thousands at public expense, on the other. I believe my research has contributed to enriching knowledge of Jerzy Wróblewski's comic work, of the Polish comics culture and also of the history of Polish post-war culture, in which Wróblewski's work should be included. As I wrote in the final part of the book: If [...] popular culture is to be treated as an immanent part of culture of a given country [...], and not its separate, (worse) part, it must be concluded that Jerzy Wróblewski's comics art deserves such recognition (Jaworski, 2015, p. 335).

\section{REFERENCES}

Gaumer, P., Rosiński P. (2015). Grzegorz Rosiński. Monografia. Warszawa: Egmont. Jaworski, M. (2015). „Urodzony, żeby rysować”. Twórczość komiksowa Jerzego Wróblewskiego. Toruń: Wydawnictwo Naukowe UMK.

Rusek, A. (2001). Tarzan, Matołek i inni. Cykliczne historyjki obrazkowe w Polsce w latach 1919-1939. Warszawa: Biblioteka Narodowa.

Rusek, A. (2010). Leksykon polskich bohaterów i seriali komiksowych. Poznań: FundacjaTranzyt/CENTRALA Central Europe Comics Art.

Rusek, A. (2011). Od rozrywki do ideowego zaangażowania: komiksowa rzeczywistość w Polsce w latach 1939-1955. Warszawa: Biblioteka Narodowa.

Szyłak, J. (1998). Komiks: świat przerysowany. Gdańsk: Wydawnictwo słowo/obraz słowo/obraz terytoria. 
Szyłak, J. (2000). Komiks. Kraków: Znak.

Szyłak. J. (2000). Poetyka komiksu. Warstwa ikoniczna i językowa. Gdańsk: Wydawnictwo słowo/obraz terytoria.

Toeplitz, K. T. (1985). Sztuka komiksu. Próba definicji nowego gatunku artystycznego. Type. Warszawa: Czytelnik

Corresponding author at: Marcin Jaworski, Department of Art Education, Nicolaus Copernicus University, ul. Sienkiewicza 4, 87-100 Toruń, Poland

E-mail: maul@poczta.onet.pl 